\title{
Analysis of the Safety Risks of Working With Job Safety Analysis On the Installation of Scaffolding at PT. Jaya Konstruksi Jakarta
}

\author{
Evi Mulyaningsih \\ Program studi Magister Keselamatan dan Kesehatan Kerja, Fakultas Kesehatan Masayarakat \\ Universitas Muhammadiyah Jakarta, Indonesia \\ Email : Mulyaningsih.evi@gmail.com
}

\begin{abstract}
.
Scaffolding has a large potential risk of accidents, this is due to more diverse work processes and scaffolding installation activities. The purpose to this study was to determine the level of occupational safety risk in the scaffolding installation process. The method of study is qualitative method. There are 223 people in the study population with the Slovin Formula, we got at least 30 people. The sample used 33 people by purposive sampling technique with criteria of worker who have worked for 3 year working, 1 year scaffolding installation experience and the education minimize of senior high school. The data collected by deeply interview, document study, observation and questionnaire. Data analyzing by data reduction, data presentation and conclusion of verification. The results of study shows a. there are 80 potential hazard risk identification that can pose a risk hazard; $b$. the consequences and probability result is $5 \times 5,4 \times 3,3 x$ and $2 x 1$; c. the risk assessment are $37,3 \%$ extreme risk, $30 \%$ high risk, $28.7 \%$ moderate risk and $3.7 \%$ low risk. Scratched risk is 0.038 on housekeeping at the level low risk so can be concluded that most of scaffolding installation risk are at level extreme and high risk.
\end{abstract}

Keywords: Scaffolding, Level of Scaffolding Risk

\section{INTRODUCTION}

The industrial world in the era of today is experiencing a rapid development, which is characterized with the development of science and technology that will result in increased competition, especially among the industry towards industry 4.0, so that the human or worker is required to prepare in the face of the development of science and technology in their respective fields. One industry in the field of construction that provides construction services that play an important role in national development and also the construction sector is significant to the occurrence of accidents or accident.

Construction work is a job that involves technology engineering involving engineering consultants as a planner(the front end of engineering and engineering design), the contractor as the executor as well as supervisory consultants. All the elements are good planners, contractors and supervisors and workers have a contribution of its own in safety construction field. Construction work on the construction of high-rise buildings used for offices, school buildings, residential dwellings and others, which is done in a relatively short time with the workers that dense would activity with the risk - the risk of harm or hazardyang quite high, for example; the work of lifting heavy objects (manual handling and lifting), working at height (working at height), as well as work in confined spaces (confinde space). The effect of the work-such work, in the event of an accident is the destruction of equipment and death and lifelong disability.

Based on data from the International Labour Organization (ILO) in 2017, every 15 seconds there are 153 workers experience of workplace accidents. Every day there are 6300 people died as a result of occupational diseases and work accidents, in a year there are more than 2.3 million deaths and occupational diseases and workplace accidents (ILO, 2017) on the labor force the international level. It can be seen from the number of occupational accidents that tend to increase a total of 123 
thousand cases with an increase of $20 \%$ with the payment of claims amounting to Rp. 971 billion larger than the year 2016 amounting to Rp.792 billion (BPJS, 2017).The number of occupational accidents continued to show a rising trend. Social security agency (BPJS) Employment record, in 2017 the number of workplace accidents reported to achieve 123.041 case, while all the 2018 reach 173.105 cases with claim of Accident insurance (JKK) amounting to Rp 1.2 trillion.Act No. 1 Year 1970 on work safety Article 2 paragraph 2 letter c is done the construction, repair, maintenance, cleaning or demolition of, houses, buildings or other building, including the building of irrigation, channels or tunnels under the ground and so on or where do construction work. The number of occupational accidents in Indonesia is still very bad, ie; ranked 26 out of 27 countries and there are 51.523 the case of a work accident, there is 46.264 case of injury, 2004 the case of the death of, 317 cases record the total and 6400 defective part (Suardi, 2016).

Overall these effects will affect the schedule completion of the project, as well as swelling the cost of construction (Dewobroto, 2007). The accident happened at a construction work are mostly caused by labor unions or are not experienced to what he was doing, the equipment that are not suitable for use, working conditions are not safe or do the job (unsafe action) and unsafe conditions (unsafe condition) also make decisions that are less precise when phases of engineering and design. then the cause of the accident the other is the responsibility of the contractor and management company to pay attention to such things (Dewobroto, 2007).

The aspect of safety plays a role in minimizing the risk or reduce the risk of hazards in the workplace. In this case the process safety should receive primary attention for the sake of successful corporate programs in order to increase productivity for the company and can create security and comfort of work.

Company PT. Jaya Construction is engaged in construction services, started since its inception i.e. since 1996 based in Jakarta, this Study was conducted on building projects SDN 18, Kramat Jati, Jakarta, which has the number of workers amounted to 223 people.

Table.1. Workers on the building projects SDN 18, Kramat Jati, Jakarta

\begin{tabular}{|l|c|}
\hline \multicolumn{1}{|c|}{ Pekerjaan } & Jumlah \\
\hline Project manager & 1 \\
\hline Deputy manager & 1 \\
\hline Part Of The Construction & 2 \\
& 8 \\
\hline - Chief executive & 4 \\
\hline - Implementing & 7 \\
\hline Part Engineering & 3 \\
\hline The Administration and finance & 10 \\
\hline The human Resources & 33 \\
\hline Part K3 & 154 \\
\hline Implementing scaffolding & 223 \\
\hline
\end{tabular}

Installation of scaffolding or scaffolding is a planning sketch of the form of the image which shows the size of the distance from Install standard, ledger, transom and position the draft of the brace as well as order any other amplifier. On the maintenance of scaffolding equipment there is an inspection (before installation, during installation and periodic inspection), use and dismantling of scaffolding. Based on the report of the accident in PT. Jaya Konstruksi Jakarta in 2017 there has been an accident or accident as much as 10 (ten) workers, including 7 (seven) workers sourced from exposed equipment and materials such as; crushed the iron, the frame, the fall board, a hammer, a wrench for the booster connection pipe, while the 3 (three) workers who slipped, bumped the diagonal bracing and falling from the height difference of the surface of the ground floor work level 1 (one). Based on the observation on the installation of scaffolding and interview to Experts K3 Young Construction, supervisors and technicians of the scaffold as well as the executive personnel and workers, the researchers conducted research with the title analysis and risk control occupational safety with Job Safety Analysis (JSA) showing out the installation of scaffolding at PT. Jaya Construction on the building construction SDN 18, Keramat Jati, Jakarta. 


\section{METHODS RESEARCH}

Qualitative method is a type of research conducted to describe and analyze about the reality of what happened on the object to be studied.(Denzin and Lincoln, 1994:2)."Qualitative research is research that focuses on the multi-method, involving the approach of interpretive, naturalistic, approach to the subject matter ". Researchers trying to photograph the events and happenings that become the center of attention which is then depicted or described as the absence of, the installation of the scaffold by the method of hazard identification and analysis risk control using the checklist hazard identification and risk assessment, through risk analysis. The population of this research on all the Construction workers in building construction SDN.18 East Jakarta amounting to 223 workers, while the sample amounted to 30 people determined using the slovin formula,determine the sample with how to assign special characteristics with the aim of the study to answer the research problems are strengthened according to Notoatmodjo (2010). Data were collected through observation, study of documentation and in-depth interviews.

Methods of data analysis begins with analyzing the risks to determine the level of risk or risk level obtained from the results of the calculation of consequence and probability based on semiquantitative analysis Standards Australia/Standards New Zealand 4360 2004, in tables 2.3, 2.4 and 2.5. Next compare the level of risk with the existing criteria in the table.2.19 and 2.20.After that is done the risk evaluation and control risk.The process of data analysis was done at the time of the beginning or the primery research conducted with data collection, then the processing of the data until the end of the activity field, if it is felt his or her data is still lacking, it will be held and the collection of additional data, the following can be presented a diagram of the flow chart. The technique of data validity is done melaluitriangulasi Sources, triangulation of Methods, triangulation with the source.

\section{RESULTS}

Based on the results of a report check list identification for the consequences and probability of harm on thirty (30) workers on the installation of scaffolding PT. Jaya Construction to building construction SDN 18, Keramat Jati, Jakarta, is as follows :

Table 2. Report the Results of the Consequence and the Probability of Installation of Scaffolding.

\begin{tabular}{|c|l|c|c|c|c|}
\hline No & Kategori & Konsekuensi & Probabilitas & Risiko & Tingkatan \\
\hline 1 & Claim & 5 & 4 & 20 & EXTRIM \\
\hline 2 & Claim & 5 & 4 & 20 & EXTRIM \\
\hline 3 & Claim & 5 & 4 & 20 & EXTRIM \\
\hline 4 & Claim & 5 & 4 & 20 & EXTRIM \\
\hline 5 & Claim & 5 & 4 & 20 & EXTRIM \\
\hline 6 & Claim & 5 & 4 & 20 & EXTRIM \\
\hline 7 & Claim & 5 & 4 & 20 & EXTRIM \\
\hline 8 & Claim & 5 & 4 & 20 & EXTRIM \\
\hline 9 & Claim & 5 & 4 & 20 & EXTRIM \\
\hline 10 & Claim & 5 & 4 & 20 & EXTRIM \\
\hline 11 & Claim & 5 & 4 & 20 & EXTRIM \\
\hline
\end{tabular}




\begin{tabular}{|c|c|c|c|c|c|}
\hline 12 & Claim & 5 & 4 & 20 & EXTRIM \\
\hline 13 & Claim & 5 & 4 & 20 & EXTRIM \\
\hline 14 & Claim & 5 & 4 & 20 & EXTRIM \\
\hline 15 & Claim & 5 & 4 & 20 & EXTRIM \\
\hline 16 & Claim & 5 & 4 & 20 & EXTRIM \\
\hline 17 & Claim & 5 & 4 & 20 & EXTRIM \\
\hline 18 & Claim & 5 & 4 & 20 & EXTRIM \\
\hline 19 & Claim & 5 & 4 & 20 & EXTRIM \\
\hline 20 & Claim & 5 & 4 & 20 & EXTRIM \\
\hline 21 & Claim & 5 & 4 & 20 & EXTRIM \\
\hline 22 & Claim & 5 & 4 & 20 & EXTRIM \\
\hline 23 & Claim & 5 & 4 & 20 & EXTRIM \\
\hline 24 & Claim & 5 & 4 & 20 & EXTRIM \\
\hline 25 & Claim & 5 & 4 & 20 & EXTRIM \\
\hline No & Categories & Konsekuensi & Probabilitas & Risiko & Tingkatan \\
\hline 1 & Stricken & 4 & 3 & 12 & HIGH \\
\hline 2 & Stricken & 4 & 3 & 12 & HIGH \\
\hline 3 & Stricken & 4 & 3 & 12 & $\mathrm{HIGH}$ \\
\hline 4 & Stricken & 4 & 3 & 12 & HIGH \\
\hline 5 & Stricken & 4 & 3 & 12 & HIGH \\
\hline 6 & Stricken & 4 & 3 & 12 & HIGH \\
\hline 7 & Stricken & 4 & 3 & 12 & HIGH \\
\hline 8 & Stricken & 4 & 3 & 12 & HIGH \\
\hline 9 & Stricken & 4 & 3 & 12 & HIGH \\
\hline 10 & Stricken & 4 & 3 & 12 & HIGH \\
\hline 11 & Stricken & 4 & 3 & 12 & HIGH \\
\hline 12 & Stricken & 4 & 3 & 12 & $\mathrm{HIGH}$ \\
\hline 13 & Stricken & 4 & 3 & 12 & HIGH \\
\hline 14 & Stricken & 4 & 3 & 12 & HIGH \\
\hline 15 & Stricken & 4 & 3 & 12 & $\mathrm{HIGH}$ \\
\hline
\end{tabular}




\begin{tabular}{|c|c|c|c|c|c|}
\hline 16 & Stricken & 4 & 3 & 12 & HIGH \\
\hline 17 & Stricken & 4 & 3 & 12 & HIGH \\
\hline 18 & Stricken & 4 & 3 & 12 & $\mathrm{HIGH}$ \\
\hline 19 & Stricken & 4 & 3 & 12 & HIGH \\
\hline 20 & Stricken & 4 & 3 & 12 & HIGH \\
\hline 21 & Stricken & 4 & 3 & 12 & HIGH \\
\hline 22 & Stricken & 4 & 3 & 12 & HIGH \\
\hline 23 & Stricken & 4 & 3 & 12 & $\mathrm{HIGH}$ \\
\hline 24 & Stricken & 4 & 3 & 12 & HIGH \\
\hline No & Categories & Konsekuensi & Probabilitas & Risiko & Tingkatan \\
\hline 1 & Depressed & 3 & 2 & 6 & MODERATE \\
\hline 2 & Depressed & 3 & 2 & 6 & MODERATE \\
\hline 3 & Depressed & 3 & 2 & 6 & MODERATE \\
\hline 4 & Depressed & 3 & 2 & 6 & MODERATE \\
\hline 5 & Depressed & 3 & 2 & 6 & MODERATE \\
\hline 6 & Depressed & 3 & 2 & 6 & MODERATE \\
\hline 7 & Depressed & 3 & 2 & 6 & MODERATE \\
\hline 8 & Depressed & 3 & 2 & 6 & MODERATE \\
\hline 9 & Depressed & 3 & 2 & 6 & MODERATE \\
\hline 10 & Depressed & 3 & 2 & 6 & MODERATE \\
\hline 11 & Depressed & 3 & 2 & 6 & MODERATE \\
\hline 12 & Depressed & 3 & 2 & 6 & MODERATE \\
\hline 13 & Depressed & 3 & 2 & 6 & MODERATE \\
\hline 14 & Depressed & 3 & 2 & 6 & MODERATE \\
\hline 15 & Depressed & 3 & 2 & 6 & MODERATE \\
\hline 16 & Depressed & 3 & 2 & 6 & MODERATE \\
\hline 17 & Depressed & 3 & 2 & 6 & MODERATE \\
\hline 18 & Depressed & 3 & 2 & 6 & MODERATE \\
\hline 19 & Depressed & 3 & 2 & 6 & MODERATE \\
\hline
\end{tabular}




\begin{tabular}{|c|l|c|c|c|c|}
\hline 20 & Depressed & 3 & 2 & 6 & MODERATE \\
\hline 21 & Depressed & 3 & 2 & 6 & MODERATE \\
\hline 22 & Depressed & 3 & 2 & 6 & MODERATE \\
\hline 23 & Depressed & 3 & 2 & 6 & MODERATE \\
\hline No & & Konsekuensi & Probabilitas & Risiko & Tingkatan \\
\hline 1 & Categories & 5 & 5 & 25 & EXTRIM \\
\hline 2 & Collapsed & 5 & 5 & 25 & EXTRIM \\
\hline 3 & Collapsed & 5 & 5 & 25 & EXTRIM \\
\hline 4 & Collapsed & 5 & 5 & 25 & EXTRIM \\
\hline 5 & Collapsed & 5 & 5 & 25 & EXTRIM \\
\hline No & Collapsed & Konsekuensi & Probabilitas & Risiko & Tingkatan \\
\hline 1 & Scratched & 2 & 1 & 2 & LOW \\
\hline 2 & Scratched & 2 & 1 & 2 & LOW \\
\hline 3 & Scratched & 2 & 1 & 2 & LOW \\
\hline
\end{tabular}

The overall work of the installation of scaffolding of the type of danger-the danger of the total of the potential danger that occurs there is 80 (eighty) the potential danger posed can be measured based on each process or stages of installation of scaffolding on the building construction SDN 18, Keramat jati, Jakarta, which can be seen in figure 4.1. is as follows

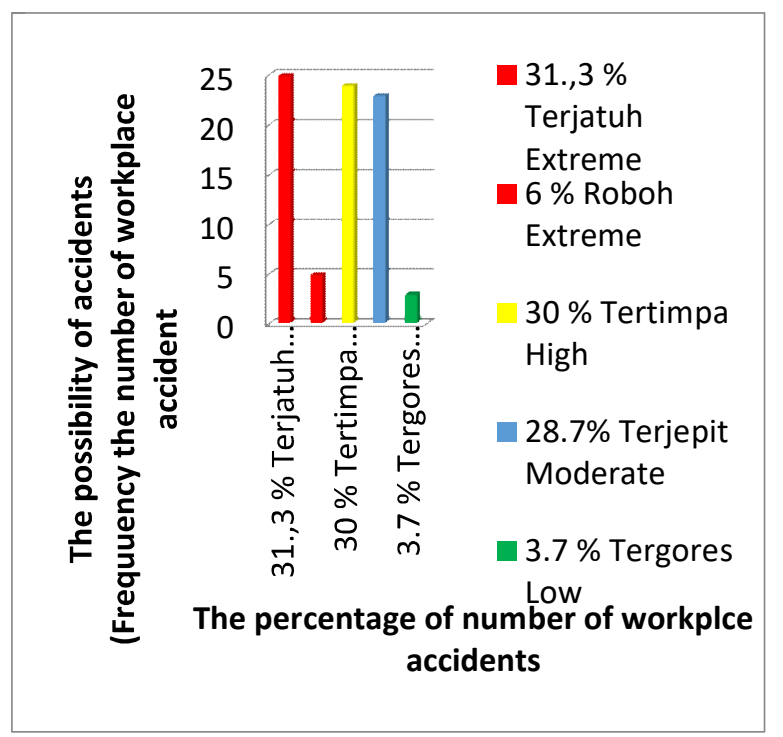

Figure 1. Graph the relationship between the probability of an accident work with a percentage of a number of accidents 
From the chart above, then most of the fall was $31 \%$ and the fall was $6 \%$ have extreme risk, then falling is a $30 \%$ risk of high and pinched is of $28.7 \%$ at risk moderate, while the most smallest scratched is $3.7 \%$ at risk low.

\section{DISCUSSION}

This study, author conducted observation, check list and interview on the process of installation of scaffolding (scaffolding) at PT.Jaya Konstruksi in Jakarta. The process of observation that is performed only by making observations on every stage of the installation of scaffolding (scaffolding). The identification and the analysis conducted on the installation of scaffolding (scaffolding) in company the only limited on the analysis and control of risk with the Job safety Analysis (JSA) on safety work on the installation of scaffolding, it is because of the time constraints of the study.

The results of the identification of safety risks working in the process of installing the scaffold, is as follows :

\section{a. The process of preparation for the transfer of the material.}

The process of preparation for the transfer of material in case of accidents the risk of falling is 0.313 which is due to the lack of adherence to SOP, safety talk and supervision and the crushed material of the scaffold is 0.300 caused the lack of compliance on SOP and supervision, this is in accordance with the theory of Heinrich which states that $88 \%$ of accidents caused by the acts or unsafe acts of people (unsafe action) and reinforced by the theory of Petersen the cause of accidents that there are ergonomic factors that can affect the activity of the workers caused by the mismatch between the facilities work which includes how to work, working position, working equipment and load lifting against workers is not appropriate in the opinion of the Sedarmayanti 2008 that the Occupational Safety and Health/K3 a Working Environment, because there are factors - factors of the working environment according to the Beautiful Rachmatiah 2012.

This is in accordance with the laws and regulations No. 1 year 1970 on work safety article 3 of the terms of workplace safety in a letter. to prevent and reduce occupational accidents and not in accordance with the Regulation of the Minister of Manpower No. Per. 03/Men/1998 regarding the work accident is an occurrence (event) that are not desired and was not previously suspected that may cause human casualties and / or property not in accordance with the Regulation of the Minister of state owned enterprises No.05/PRT/M/2014 on Guidelines for Management System of K3 Construction. The company can conduct socialization on the standard operating procedures to workers, technicians scaffolding to comply with and obey.

\section{b. The process pembaan on the jack base,the mainframe/of the frame I. and III, the cross brace and pin joints.}

1. The process of installing a jack base

The process of installing a jack base which has the risk of workers ' hands pinched is 0.287 which is due to the lack of adherence to SOP, safety talk, way and the use of personal protective equipment, in this case hazard is a condition that can create or increase the chance of loss according to the opinion of the Redja 2003 and reinforced by the opinions of Ridley and Channing 1998 that the danger or hazard is an element of potential that can cause harm, it is not appropriate in the opinion of Toriq. A. Ghuzdewan, ST, MSCE year 2015 on the health and safety of construction projects.

2. The process of installing a mainframe I, II and III.

The process of installing a mainframe that can pose the risk of Collapse is 0.060 which caused turtle adherence to SOP, safety talk and supervision, it is according to the opinion of Wiryanto Dewobroto 2010 to determine the classification of hazards in the workplace so that it can perform control and the dangers of what happens, this is reinforced by the opinion of David D Woods and Richard Cook of the year 2012 that source of danger can occur from the behavior (behavior) and the physical condition of the workers.

3. The process of installing a pipe diagonally (cross brace)

The process of installing a pipe diagonally (cross brace) that may pose a risk of falling is 0.300 caused the lack of compliance on SOP and the supervision and pinched is 0.287 which is due to the lack of 
compliance on SOP and supervision, this according to Bird, Jr. Frank E and George L, Germany 1996 that Accidents can occur, it is necessary to control to prevent accidents and reinforced the opinion of the Anizar year 2005 that the occupational health and safety important in the introduction of the causes of the accident. It is not in accordance with the opinion of the Tarwaka, PGDIP, Sc, M. Eng, 2012, that the position of the work when installing the cross brace requires the position of the ergonomic workplace to prevent workplace accidents by studying the basics of workplace safety and accident prevention in the workplace.

4. The process of installing a joint pin

The process of installing a joint pin which has the risk of workers ' hands pinchedis 0.287 which is due to the lack of adherence to SOP, safety talk and how to the use of personal protective equipment or PPE, it is that the danger is a condition that can create or increase the chance of loss according to the opinion of the Redja 2003 and reinforced by the opinions of Ridley and Channing 1998 that the danger or hazard is an element of potential that can cause harm, it is not appropriate in the opinion of Toriq. A. Ghuzdewan, ST, MSCE, 2015 at the occupational safety and health construction project.

\section{A. The process of installing a lock arm, transfer pipe railing material, install guardrail (handrail, midrail), toe board, ladder and platform.}

1. The process of installing a lock arm

The process of installing a lock arm, which may pose a risk of entrapment is 0.287 which is due to the lack of adherence to SOP, safety talk and how to use PPE, it is that installing the mainframe the first level and further mounted with a strong grip so that the scaffolding is sturdy, so the dangers of accidents at work both human casualties and property in accordance with the theory of Loss Causation Model which contains the instructions that allows users to understand how to find the important factors in order to control the widespread work accidents and reinforced with the theory of Bird and Germain, who explained that a loss (loss) is caused by a series of factors that in sequence, it is necessary to control accidents and not appropriate according to the opinion of DR. Ir. Boxed Ali Hanafiah 2005 should study the science about the construction of the soil or basic soil science.

2. The process of doing the transfer pipe railing material

The process of doing the transfer pipe railing material in case of accidents the risk of falling is 0.313 which is due to the lack of adherence to SOP, safety talk, supervision and crushed material of the scaffold is 0.300 caused the lack of compliance on SOP and supervision, according to the theory of Heinrich which states that $88 \%$ of accidents caused by the acts or unsafe acts of people (unsafe action) and reinforced by the theory of Loss Causation Model to understand how to find the important factors in order to control the widespread accidents and losses, where accidents can be caused by a mismatch between the facilities work which includes how to work, working position, working equipment and load lifting against workers is not appropriate in the opinion of the Sedarmayanti 2008 that there are other factors that affect it, namely: K3 working environment according to Indah Rachmawati 2012.

3. The process of installing a guardrail (handrail and midrail)

The process of installing guadraill (handrail and midrail) on the safety fence at the top of the right and left as well as the front and back that can pose a risk of a fall is 0.313 which is due to the lack of adherence to SOP, safety talk, supervision and crushed material of the scaffold is 0.300 caused the lack of compliance on SOP and supervision. This is according to the opinion of the Colling 1990 about understand how accidents can occur and the cause is reinforced by the opinion of the Hamsa 2006 that an activity need to be analyzed for risks, which is not appropriate according to the opinion of the Soehatman Ramli 2011 that all events that may pose a cause and a result of workplace accidents, it is necessary to perform hazard identification in risk management.

1. The process of installing a toe board (safety fence which is installed in all the higher side of the floor work).

The process of installing a toe board installed on all sides of the work floor, the minimum height of $150 \mathrm{~mm}$, a slit on the surface of the floor boards with toe board to a maximum of $10 \mathrm{~mm}$ that can pose a risk of a fall is 0.313 which is due to the lack of compliance on SOP - Standard Operating 
procedures, safety talk and supervision, the workers pinched is 0.287 which is due to the lack of adherence to SOP, safety talk and supervision, it is according to the opinion of Ridley and Channing, John, 1998, regarding the management of risks in the workplace that is reinforced by the opinion of Irham Fahmi, 2008 on the $\mathrm{K} 3$ in the management and implementation in the workplace is not appropriate in the opinion of the Soehatman Ramli 2010 about K3 management system in the construction of buildings.

\section{The process of installing a staircase or ladder}

The process of installing a staircase or ladder that may pose a risk to workers ' hands stricken is 0.300 caused the lack of compliance on SOP, supervision and pinched the material of the scaffold is 0.287 which is due to the lack of adherence to SOP, safety talk and how to use PPE, it is the opinion Kolluru 1996 that risk analysis to identify hazards and to estimate a risk to the individual, building and environment diperkuatpendapat Simanjuntak 2005 on occupational Safety is a condition of salvation which is free from the risk of accidents and damage to that includes about the condition of the building, equipment and safety conditions of workers who are not in accordance with the opinion Soehatman Ramli 2010 about K3 management system in the construction of buildings.

\section{The process of installing a platform}

The process of installing a platform or cat walk that can pose a risk of a fall is 0.313 which is due to the lack of adherence to SOP, safety talk, the use of triplex and wood as well as less scrutiny and are also at risk of pinched material of the scaffold is 0.288 which is due to the lack of adherence to SOP, safety talk and how to use PPE, it is according to the opinion Djunaedi 1999 to determine the classification of hazards in the workplace, this is reinforced by the opinion of A.M. Sugeng Budiono, 2003 that unsafe actiondan unsafe condition so as not to use the triplex and the wood on the scaffold to be able to reduced these impacts by implementing the requirements of safety and occupational health is not appropriate according to Toriq. A. Ghuzdewa, ST, MSCE, 2015 about K3 management construction project that can prevent workplace accidents in the construction environment.

\section{A. The process of installing a ledger, transom, clamp dead or alive, support scaffolding and pengkuatan diagonal laterally on the same side.}

1. The process of installing pengkuatan horizontal (ledger).

The process of installing pengkuatan horizontal (ledger) that may pose a risk of a fall is 0.313 which is due to the lack of adherence to SOP, safety talk, supervision and crushed material of the scaffold is 0.300 caused the lack of compliance on SOP and the supervision on the implementation of the project, this is according to Bird, Jr. Frank E and George L, Germany 1996 that Accidents can occur, it is necessary to control to prevent accidents and reinforced the opinion of the Anizar year 2005 that the occupational health and safety important in the introduction of the causes of the accident. It is not in accordance with the opinion of the Tarwaka, PGDIP, Sc, M.Eng, 2012, that the position of the work when installing the ledger requires the position of the ergonomic workplace to prevent workplace accidents by studying the basics of workplace safety and accident prevention in the workplace.

2. The process of installing pengkuatan vertical (transom).

The process of installing pengkuatan vertical (transom), which can pose a risk of a fall is 0.313 which is due to the lack of adherence to SOP, safety talk, supervision and crushed material of the scaffold is 0.300 caused the lack of compliance on SOP and supervision, this is in accordance with the theory of Heinrich which states that $88 \%$ of accidents caused by the acts or unsafe acts of people (unsafe action) and reinforced by the theory of Petersen the cause of accidents that there are ergonomic factors that can affect the activity of the workers caused by the mismatch between the facilities work which includes how to work, working position, working equipment and load lifting against workers is not appropriate in the opinion of the Sedarmayanti 2008 that there are other factors, namely: K3 working environment according to Indah Rachmawati 2012.

3. The process of installing a clamp die or live 
The process of installing the clamp dead or alive, that have a risk of workers ' hands pinched is 0.287 which is due to the lack of adherence to SOP, safety talk and how to use PPE, it is that the danger is a condition that can create or increase the chance of loss according to the opinion of the Redja 2003 and reinforced by the opinions of Ridley and Channing 1998 that the danger is an element of potential that can cause harm, it is not appropriate in the opinion of Toriq. A. Ghuzdewan, ST, MSCE, 2015 at the occupational safety and health construction project.

\section{The process of attaching the support scaffolding}

The process of attaching the support scaffolding that can pose a risk of scaffold collapse is 0.060 which is due to the lack of adherence to SOP, safety talk and supervision, and fall is 0.313 which is due to the lack of compliance on SOP and supervision as well as stricken is 0.300 caused the lack of compliance on SOP and supervision, it is according to the opinion of Kolluru 1996 that risk analysis to identify hazards and to estimate a risk to the individual, the building and the environment reinforced the opinion Irham Fahmi 2008 about the workplace Safety is a condition of salvation which is free from the risk of accidents and damage to that includes about the condition of the building, equipment and safety conditions of workers who are not appropriate then the need to control workplace accidents according to the opinion of DR. Ir. Boxed Ali Hanafiah 2005 should study the science about the construction of the soil or basic soil science.

\section{The process of installing pengkuatan diagonal laterally on the same side}

The process of installing pengkuatan diagonal laterally on the same side, which can pose a risk of scaffold collapse is 0.060 which is due to the lack of adherence to SOP, safety talk and supervision, and fall is 0.313 which is due to the lack of compliance on SOP and supervision as well as stricken is 0.300 caused the lack of compliance on SOP and supervision, it is according to the opinion of Kolluru 1996 that risk analysis to identify hazards and to estimate a risk to the individual, the building and the environment reinforced the opinion of Simanjuntak 2005 on occupational Safety is a condition of salvation which is free from the risk of accidents and damage to that includes about the condition of the building, equipment and safety conditions of workers who are not appropriate then the need to control workplace accidents according to the opinion of DR. Ir. Boxed Ali Hanafiah 2005 should study the science about the construction of the soil or basic soil science.

\section{B. The process Housekeeping}

Process Housekeeping or tidy up and clean up of materials and materials equipment scaffolding (scaffolding) with a neat, clean and well maintained so the risk of scratched is 0.038 which is due to the lack of compliance on SOP and how to use the PPE so that accidents can be eliminated. This is according to the guide in the field of Occupational Health and Safety or K3 of the ILO (International Labor Organization, 1989) mentions that the work accident is the incident that is unplanned and uncontrolled, caused by man, the situation and environmental factors or combination of factors factors that interfere with the work process, which can (or not) cause injuri, pain, death, damage to buildings (property) or events that are not desired and are also reinforced by the opinion of Beautiful Rachmawati 2012 that the risk of which is likely to happen be bad and detrimental. It is not in accordance with the opinion of Takashi Osada year 2011 that Housekeeping can be applied with an attitude $5 \mathrm{~S}$ to labor.

C. Prosesmenggunaan work tools, materials and personal protective equipment.

1. The process uses a working tool

The process of using the work equipment can pose a risk of falling is 0.300 caused the lack of compliance on SOP and supervision. This is according to the opinion of the Colling 1990 about understand how accidents can occur and the cause is reinforced by the opinion of the Hamsa 2006 that an activity need to be analyzed for risks, which is not appropriate according to the opinion of the Soehatman Ramli 2011 that all events that may pose a cause and a result of the work accident need to be identified in the form of a management system of occupational health and safety. 


\section{The process uses materials or material}

The process of using the material or the material will be work accidents are at risk of falling is 0.313 which is due to the lack of compliance on SOP and supervision as well as stricken is 0.300 caused the lack of compliance on SOP and supervision, this is in accordance with the theory of Heinrich which states that $88 \%$ of accidents caused by the acts or unsafe acts of people (unsafe action) and reinforced by the theory of Petersen the cause of accidents that there are ergonomic factors that can affect the activity of the workers caused by the mismatch between the facilities work which includes how to work, working position, working equipment and load lifting against workers is not appropriate in the opinion of the Tarwaka 2008 that the need to implement and carry out the audit management procedure and implementation according to IBK Bayangkara year 2015.

\section{Prosesmenggunakan personal protective equipment or PPE}

The process of using personal protective equipment without appropriate procedures can pose a risk of a fall is 0.313 which is due to the lack of compliance on SOP and supervision of the do the job put up scaffolding and fric potential accidents both human casualties and material possessions. This is in accordance with the theory of Loss Causation Model which contains the instructions that allows users to understand how to find the important factors in order to control the widespread work accidents and reinforced with the theory of Bird and Germain, who explained that a loss (loss) is caused by a series of factors that in sequence and also personal protective equipment for workers, it is necessary to control accidents and not appropriate according to the opinions of Drs. Irzal, M.Kes 2014 to learn the science basics of health and safety at work.

\section{Prosesprilaku (behavior) the capture, removal and installation of the frame and the pipe- scaffolding pipe}

The process of behavior (behavior) the capture, removal and installation of the frame and the pipes of the scaffolding, which can pose a risk of falling is 0.300 caused the lack of compliance on SOP, supervision and pinched is 0.288 which is due to the lack of adherence to SOP, safety talk and how to use PPE. This is in accordance with the theory of Heinrich which states that $88 \%$ of accidents caused by the acts or unsafe acts of people (unsafe action) and reinforced by the theory of Petersen the cause of accidents that there are the ergonomic factors which can affect the activity of the workers, where the behavior and the position of ergonomics plays an important role to prevent workplace accidents is not appropriate in the opinion of the Soekidjo Notoatmodjotahun 2012 and the need to apply management of risk according to Irham Fahmi 2008.

\section{Prosesfaktor work environment}

The process of working environment factors, which can pose a risk of a fall is 0.313 which is due to the lack of adherence to SOP, safety talk and supervision. This is in accordance with the theory of Heinrich which states that $88 \%$ of accidents caused by the acts or unsafe acts of people (unsafe action) and reinforced by the theory of Petersen the cause of accidents that there are factors ergonomic personal protective equipment that may affect the activity of the workers caused by the mismatch between the facilities work which includes how to work, working position, working equipment and load lifting against workers is not appropriate in the opinion of the Sedarmayanti 2008 that there are other factors that affect the working environment that need to handling occupational health and safety according to Indah Rachmawati 2012.

\section{CONCLUSION}

Based on the results of the research, were summed up, namely: the process of installing a mainframe/ frames risky scaffolding collapsed, the process of attaching the support scaffolding, installing pengkuatan diagonal laterally on the same side at risk of collapse, falling and falling, the process of the use of personal Protective Equipment (PPE) and factors - factors of work environment physics and chemistry are at risk of workers falling, the preparation of the transfer material, the transfer pipe railing, installing pengkuatan horizontal (ledger), installing pengkuatan vertical (transom), installing guadrail (handrail, midrail) and environmental factors work risk of workers 
falling and falling, the process of installing a toe board,installing a platform that is at risk of falling and pinched, the process of behavior take the frame and pipe scaffolding at risk of falling, the process of installing a cross brace, install the ladder, installing the frame and pipe scaffold as well as the use of work equipment risk stricken and pinched, the process of the use of the working tools, the behavior of the lifting frame and pipe scaffolding at risk of falling and scratched, the process of installing a jack base, install the lock arm danmemasang clamp live or die risk pinched, process of housekeeping at risk of scratched.

The level of risk of harm work safety at every stage - the stages in the process of installing the scaffolding (scaffolding) is extrime in the process of installing the frame I, II and III as well as the support scaffold and pengkuatan diagonal laterally on the same side, can cause risikoperancah collapsed, unstable and bouncy, with a value of 25 on the risk level is very high, extrime in the process of preparation of the transfer material before the installation of the scaffolding, installing the frame IV, the transfer pipe railing, toe boards, Platforms and working environments, can be dropped, with a value of 20 on the risk level of very high, high in the process of the transfer pipe railing, cross brace, guadrail, ledger, transom, ladder, using tools, materials behavior taking, lifting and installing the pipes of the scaffolding(scaffolding), which can cause risikopekerja can be overwritten, with the value of 12 on the level of risk high(high), moderate in the process of installing a jack base, joint pin, arm lock, clamp dead or alive, toe board, use of tools and materials, the behavior of take and lift the scaffold and clamp live or die, which can cause risikopekerja can be pinched, with a risk value of 6 on the level of risk being, low on the process of Housekeeping and use of tools and materials or material,which may pose a risk to the worker is scratched with a risk value of 2 on the level of risk small or low(low).

\section{REFERENCE}

[1] AS/NZS 4360, (2004). 3rd Edition The Australian And New Zealand Standard on Risk Management Broadleaf Capital Internasional Pty Ltd. NSW Australia.

[2] Bayangkara, IBK (2015),Audit Manajemen:Prosedur dan Implementasi,Edisi kedua, Salemba, Jakarta-

[3] Bird, J. at.al. (1996),Practical Loss Control Leadership, Leganville, Georgia.

[4] Bryan Alfons. (2013), Manajemen Risiko Keselamatan dan Kesehatan Kerja (K3) Pada Proyek Pembangunan RukoOrlens Fashion Manado,FK- Samratulangi

[5] Cooling, D. A, (1990),Industrial Safety Management and Technology,New Jersey : Prentice Hall.

[6] Creswell,J.W. (2016), Research Design: Pendekatan Metode Kualitatif, Kuantitatif, dan Campuran, Yogyakarta: Pustaka Pelajar

[7] Cross, J. (2015), Study Notes SESC 9211, 1998, Risk Management, Departemen of Safety Science University of New South Wales.

[8] Darmawi,H. (1990),Risiko yang Kemungkinan terjadi Berakibat Merugikan, Erlangga, Jakarta.

[9] David D W. and Cook, R. (2012),Behind Human Error, Second Edition, Leganville, Georgia

[10] Denzin, N.K., and Lincoln,Y.S. (1994),Handbook of Qualitative Research, Thousand Oaks, C: Sage.

[11] Departemen Tenaga Kerja - JICA (2009),Teknisi Scaffolding, Edisi revisi Projeck JICA - Depnaker

[12] Dewobroto, W. (2010), Struktur Baja, prilaku,Analisis dan Desain, Second Edition, Erlangga, Jakarta.

[13] Dewi Juliatin. (2015), Risk Assessment K3 Pada Pengoperasian Scaffolding Pada Proyek Pembangunan Hotel Gatot Subroto, FKM-Universitas Sumatera Utara, Medan

[14] Emzir, (2016),Metodologi Penelitian Kualitatif: Analisis Data, Cet 5. Jakarta: Rajawali Pers.

[15] Ervianto, W.I. (2007),Manajemen Proyek Konstruksi, Alfabeta,Bandung

[16] Fabricatus, G.U. (2010),Keselamatan Konstruksi dengan Perancah, Bunga rampai Hiperkes dan Keselamatan Kerja, Edisi ke Empat, Semarang, Universitas Diponegoro.

[17] Fahmi, I. (2012),Manajemen Risiko Teori, Kasus dan Solusi, Alfabeta, Bandung

[18] Fine, W.T, (1971),Mathematical Evaluation for Controlling Hazard, Naval Ordance Laboratory White OAK, Maryland.

[19] Fisk, (1997),Risk is Probabillity Accident, Departemen of Safety Science University of New South Wales

[20] Geotsch, D. (1996),Occupational Safety and Health For Technoloists, Engineers and Manager, 2 rd Edition, Departemen of Safety Science University of New South Wales.

[21] Hanafi,M.M. (2016),Manajemen Risiko, UPP STIM YKPN, Jakarta

[22] Hanafiah, K.A. (2007), Konstruksi kekuatan Tanah, Erlangga, Jakarta. 
[23] Heinrich, H. W. (1980),Industrial Accident Prevention. New YORK : McGraw-Hill Book Company

[24] ILO. (2009),Potensi Bahaya dan Risiko Terhadap Keselamatan dan Kesehatan Kerja. Jakarta: PT. Pustaka Binaman Pressindo

[25] Iskandar, (2009),Metode Penelitian Kualitatif,Jakarta: IKAPI.

[26] Julian. B. O. (1995),Fundamentals of Industrial Hygiene, Third Edition, National Safety Council. USA.

[27] Kolluru, RaoV, et al, (1996),Risk Assessment and management Handbook, McGrow-Hill, Inc. New York.

[28] Mahendar, F. Darminto P. (2013), Identifikasi Bahaya, Pengendali Resiko Dan Keselamatan Kerja Pada Bagian Bengkel Repair Galangan Kapal Dengan Menggunakan Metode Job Safety Analysis (JSA) PT Indah Semarang

[29] Mefa Raudhatin Jannah. ( 2018), Analisis Risiko Keselamatan dan Kesehatan Kerja (K3) melalui pendekatan HIRADC dan Metode Job Safety Analysis (JSA) Pada Studi Kasus Proyek Pembangunan Menara X di Jakarta, Universiats Brawijaya, Malang, Jawa Timur.

[30] Moleong, Lexy J. (2009),Metode Penelitian Kualitatif, Bandung: Remaja Karya

[31] Notoatmojo, (2010), Metodelogi penelitian, PT. Pustaka, Jakarta.

[32] Osada, T. (2011), 5S - Seiri, Seiton, Seiso, Seiketsu, dan Shitsuke. PPM - Bisnis, Jakarta

[33] Peraturan Menteri Tenaga Kerja dan Transmigrasi Republik Indonesia Nomor 1 Tahun 1980 TentangKeselamatan dan Kesehatan Kerja Pada Konstruksi Bangunan, Departemen Tenaga Kerja dan Transmigrasi REpublik Indonesia, Jakarta

[34] Persada, B. (2015),Risk Assessment K3 Pada Proses Pengoperasian Scaffolding Pada Proyek Apartemen. PT.X Di Surabaya, The Indonesian Journal of Occupational Safety and Health, 199-210

[35] PT. Jakon, Jakarta Timur (2017),Laporan Kecelakaan pada Jam Kerja, Periode Bulan Januari 2017 Desember 2017, Jakarta, pada bagian P2K3 PT. Jakon, Ceger Permai, Jakarta Timur.

[36] Rachmawati, I. (2015)Penerapan Keselamatan dan Kesehatan Kerja pada Lingkungan Kerja, Bunga rampai Hiperkes dan Keselamatan Kerja, Edisi ke Empat, Semarang, Universitas Diponegoro

[37] Ramli, S. (2010),Sistem Manajemen Keselamatan dan Kesehatan Kerja OHSAS 18001. Jakarta: Dian Rakyat

[38] Rejda, G. E. (2010),Principles of Risk Management and Insurance. Tenth Edition. Person Education Inc.

[39] Reny Indrayani (2013), Analisis Risiko Keselamatan Kerja pada Proyek Pengembangan Bandara InTernasional Juanda Terminal 2- Surabaya

[40] Ridley and Channing (1998),Risk Management Safety at Work, Butterworh-Heinemann, Elsivier Science, Ltd.

[41] Ridley,J. (2008),Kesehatan Dan Keselamatan Kerja, Third Edition, Erlangga, Jakarta

[42] Rowe (1977),Estimation of Risk Management. New Jersey : Prentice Hall.

[43] Santoso, B. (2009),Manajemen Proyek pada Konsep dan Implementasi. Graha Ilmu, Yogyakarta.

[44] Sedarmayanti. (2011),Tata Kerja dan Produktivitas Kerja : Suatu Tinjauan dari Aspek Ergonomi atau Kaitan antara Manusia dengan Lingkungan kerjanya. Bandung : CV. Mandar Maju.

[45] Silalahi, B.N.B, dan Silalahi, R.B. (1995), Manajemen Keselamatan dan Kesehatan Kerja, PT. Pustaka Banaman Pressindo Dan Lembaga PPM, Jakarta.

[46] Slote, Lawrence, (1987),Handbook of Occupational Safety and Health New York : New York University.

[47] Soputan, G.E. M. at. al. (2014), Manajemen Resiko Keselamatan dan Kesehatan Kerja (Study Kasus Pada Pembangunan Gedung SMA Eben Haezar), Jurnal Ilmiah Media Engineering Vol.4 (229-238) ISSN: 2087-9334,

[48] Sugioyono, (2010), Metode Penelitian Pendidikan, Pendekatan Kuantitatif dan kualitatif, dan $R \& D$, Bandung: Alphabeta

[49] Sugiyono, (2010), Metode Penelitian Pendidikan, Bandung : IKAPI

[50 Suma'mur, PK, (2001), Keselamatan Kerja dan Pencegahan Kecelakaan Kerja, Jakarta : PT. Toko Gunung Agung.

[51] Sumadinata,N.S.(2007), Metode Penelitian Pendidikan,Bandung:RemajaRosdakarya,

[52] Tamrin,A.G.(2008),Teknik Konstruksi Bangunan Gedung, Pusat Perbukuan Pendidikan nasional, Jakarta

[53] Tarwaka,(2008),Keselamatan dan Kesehatan Kerja, Manajemen dan Implementasi K3 di Tempat Kerja, Harapan Press Surakarta.

[54] Toriq. A. G. (2014), Keselamatan dan Kesehatan Kerja Pada Proyek Konstruksi, Erlangga, Jakarta.

[55] Wicaksono,B.D.(2018),Identifikasi Bahaya Pada Pemasangan Scaffolding dengan Metode Job Safety Analysis di PT. Sarana Duta Mandiri. Skripsi, Universitas Airlangga.

[56] Yudha Bagus Persada. (2017), Risk Assessment K3 Pada Proses Pengoperasian Scaffolding Pada ProyekApartemen PT. X di Surabaya, FKM-Propinsi Jawa Timur. 